\title{
When the Practice Gets Complicated: Human Rights, Migrants and Political Institutions
}

\author{
Jelena Belic
}

\section{Introduction}

The triad of terms in the subtitle may make it sound as if this chapter will introduce quite a complex argument. Indeed, it may appear to take a lot of argumentative work to connect human rights, migrants and political institutions. Yet, the argument presented in this chapter is not a complex one. On the contrary, it builds on a simple and broadly shared intuition that human rights are the rights of all human beings, including migrants. In this chapter, I set out to explore the implications of the universality of human rights for conceptualizing their political role.

In the recent debate concerning the nature and function of human rights, more and more voices argue that a theory of human rights needs to account for the political role human rights play in practice. Two aspects of that role are particularly salient in these discussions. Namely, human rights not only constrain the states' conduct but may also provide pro tanto reasons for international intervention (Rawls 1999; Raz 2007; Beitz 2009). By defining human rights as a necessary condition of state legitimacy, this view focuses on the human rights of those residing within states' borders and the correlated duties of their own states. However, this view does not seem to capture well the complexity of contemporary human rights practice. For, if we take seriously universality of human rights, then their political role cannot be narrowed down to the relation between states and their citizens, but also needs to explain the relationship between individuals and all political institutions (Peter 2013). In this regard, the human rights of migrants seem to be a good litmus test.

It is ordinarily thought that individuals are morally entitled to human rights irrespective of the place they find themselves: ceteris paribus, residing out of the country of one's nationality should not affect her human rights entitlements; but given the way states tend to treat migrants,

\footnotetext{
* This is an (almost) final version of the chapter that was published in Moral and Political Conceptions of Human Rights: Implications for Theory and Practice, Reidar Maliks and Johan Schafer (eds.), Cambridge University Press (2017), pp. $157-180$

* I have significantly benefited from discussing the earlier versions of the chapter with Zoltan Miklosi, Andres Moles, Janos Kis, Johan Karlsson Schaffer, Luise Katharina Muller, Christian Barry, Bob Goodin, Reidar Maliks, and Laura Valentini.
} 
often it does. Yet, if we accept that human rights are universal as well as claimable, then we need to clarify in what sense the human rights of migrants are claimable against foreign states. Considering this aspect of the claimability of human rights is important for two reasons. First, the current forcible displacement crisis shows how states too easily trade-off the human rights of migrants for the rights of their citizens. I call this the trade-off problem. This kind of trade-off decreases the normative significance of the human rights of migrants, which further questions the universality of human rights as such. Therefore, any conception of human rights that considers them universal has to make the rights of migrants and those of citizens co-possible. Second, thinking about claimability of the human rights of migrants against foreign states can also reveal a critical force of human rights, and help us evaluate the existing practice accordingly.

The chapter proceeds as follows. I start by describing the approach I am taking here as a version of the moral conception. Second, I explain what kind of challenge is raised by the relationship between migrants and foreign states. I then focus on the universality of human rights and show how it is reflected in their current political role. In the fourth section, I undertake a threefold task. First, I introduce the distinction between human rights as external reasons, i.e. common humanity, and as deliberated internal reasons, i.e. reasonable acceptability. In the subsequent two sections, I show why human rights taken as external rather than as deliberated internal reasons can better address the trade-off problem. In the end, I draw implications for conceptualizing the relation between migrants and states.

\section{Human Rights: Moral and/or Political?}

Let me begin by describing a theoretical landscape and situating the approach I will take here. Human rights appear to have a dual nature. On the one hand, they are moral entitlements of all human beings possessed in virtue of common humanity. On the other hand, human rights are political in the sense that they place constraints over political institutions' conduct. Recently, philosophers have started conceptualizing these two aspects of human rights, i.e. moral and political one, in a way that makes them mutually exclusive. Thus, the moral conception holds that human rights are moral rights that individuals hold independently from the existing institutional arrangements (Simmons 2000; Griffin 2008). The political conception, by contrast, defines human rights in terms of the role they play in giving reasons for actions in a global political discourse (Rawls 1999; Raz 2007; Beitz 2009). However, conceptualizing the moral and 
political aspects of human rights as mutually exclusive threatens to rob both conceptions of their explanatory force. The moral conception is often objected to being unable to explain a distinctive role human rights play against institutions, while the political conception is said to be incapable of explaining why we have the rights we have.

In the more recent literature on this matter, philosophers started taking the "middle ground" approach. For instance, the structural pluralist account attempts to preserve the moral nature of human rights, while accounting for their role against political institutions as the primary duty bearers (Barry and Southwood 2011). Similarly, one can argue that the political and the moral conception are complementary, and we need to combine them if we want to understand contemporary human rights practice (Gilabert 2011). The middle ground approach is also favored by the freedom-centered view according to which human rights are grounded in a Kantian conception of the innate right to freedom, and political institutions are constitutive of human rights (Valentini 2012). All these approaches seem successful in reconciling the moral and political aspects of human rights. Importantly, neither is committed to the view that states are the only primary duty bearers.

Nonetheless, this cannot be the whole story - the point is not only to show that human rights as moral rights are consistent with taking political institutions as the primary duty bearers but also to explain distinctive political implications human rights so understood may have. This is important since it can help us to better understand the role human rights play and to fully grasp their critical potential. I take on that task here. More specifically, I will defend a version of the moral conception that articulates political implications of human rights taken as moral rights and based on this offers a normative account of the role the human rights of migrants play against foreign states. I will start making my case by describing a challenge that the human rights of migrants raise for states.

\section{Migrants and States}

Migrations are a persistent feature of the world that raises a set of contestable issues concerning the relationship between states and foreigners. ${ }^{1}$ The current unprecedented displacement of

\footnotetext{
${ }^{1}$ To be sure, individuals come into contact with foreign states even when they reside in their home states by virtue of being affected by states' foreign policies. However, addressing this issue would take us too far from the present discussion. For the seminal discussion of the problem cross-border affectedness creates for territorially limited demos, see Robert E. Goodin 2007. "Enfranchising All Affected Interests, and Its Alternatives," Philosophy and
} 
people reveals a need for a critical assessment of existing practices as well as a proper specification of the relationship between migrants and different kinds of political institutions. The number of international migrants has reached 244 million in 2015. This figure includes almost 20 million refugees (UN International Migration Report 2015). In the light of these considerations, we need to identify what human rights migrants are entitled to and accordingly, how they should be treated by the foreign states. ${ }^{2}$ For instance, should economic migrants have the same status as refugees? Are there justifiable limits to a number of refugees that a receiving country can accept? Can receiving states treat migrants however they find appropriate? The current refugee crisis shows that this indeed can be the case in practice since rights set forth by international conventions are often set aside even by law-abiding states. In other words, states too easily trade-off the human rights of migrants for those of their citizens. The trade-off problem appears whenever governments, in the name of legitimacy-related reasons owed to their citizens, downplay claims of migrants. To be sure, we can question the governments' rhetoric that rights of citizens clash with rights of migrants, but that would be a too easy task to do. Here I take the trade-off at its face value and consider ways in which it can be constrained.

The trade-off problem raises two morally pressing questions. First, in what sense do migrants have human rights? Second, if migrants do have human rights, how can they claim them against foreign states? Let me emphasize that I am focusing on a generic category of migrants, meaning all those that cross international borders for whatever reason. While different categories of migrants, e.g. refugees and economic migrants, are entitled to different sets of legal rights, what they have in common is the entitlement to at least minimal human rights. Since in the chapter I aim to articulate possible political implications of universal human rights, these differences in legal entitlements do not affect my argument. Even more, to focus on the way states treat refugees would only amount to criticizing states for violating international refugee law. The point I want to make here is more general, for it aims to offer a normative account of such treatment able to address any trade-off between the human rights of migrants and those of citizens, irrespective of what particular situation of these migrants is.

Public Affairs 35/1: 40-68; for the reply showing that such affectedness need not entail entitlement to rights of participation, see Zoltan Miklosi 2012. "Against the Principle of All Affected Interests," Social Theory and Practice 38/3: 483-503

${ }^{2}$ There is a growing body of law setting forth rights of migrants, the most important being "International Convention on the Protection of the Rights of All Migrant Workers and Members of Their Families," 1990. 
First, if we take human rights as weighty claims which are "generally suspect" to tradeoffs (O’Neill 2015, p. 73), and if, at the same time, the human rights of migrants are so easily traded off, it makes one wonder if migrants have human rights at all. One can object here that the human rights of migrants are different from the rights of citizens and that the latter surely have priority. Indeed, legally speaking, states parties to international conventions undertake obligations to primarily protect the rights of their own citizens. However, while citizenship rights normally incorporate human rights, they do not exhaust it. For instance, all persons have a claim against torture whether or not they are citizens of a state concerned. Therefore, while citizens are entitled to citizenship rights; human rights are universal entitlements of all human beings. To ignore this point would amount to identifying human rights with rights of citizenship, in which case one could wonder why we need a category of human rights at all.

The trade-off problem is distinctive in one more respect. Namely, the human rights of migrants are often set aside for the sake of maximizing interests of citizens. For instance, governments often invoke reasons of security or those of protecting the welfare rights of their citizens to justify strict immigration policies. Leaving aside empirical controversies underpinning such rationale, what this shows is that such aggregation of the citizens' interests easily outweighs individual claims of migrants. Yet, this conflicts with a broadly shared intuition that persons do not lose their human rights once they cross international borders. Therefore, if we want to show that migrants are, just as all other human beings, entitled to human rights, we need to explain in what sense their rights are claimable against foreign states.

To conceptualize the claimability of the human rights of migrants we need to start from the political nature of human rights. Namely, human rights are considered political by virtue of constraining states' conduct. Since state institutions are "inescapable" and heavily shape individual lives, human rights impose limits on them (Valentini 2012a). If the coercive impact states' institutions have over individuals residing within their borders is what explains the political nature of human rights, one can argue that the same holds for those attempting to enter. Indeed, state boundaries are instances of force that is exercised over both members and nonmembers. This kind of coercion is inescapable for all those attempting to enter a foreign state (Abizadeh 2008). If this argument is sound, then we should start thinking whether the human rights of migrants can serve as evaluative criteria for states' institutions. For instance, is it plausible to argue that violations of the human rights of migrants can pro tanto justify 
intervention the same way it does in a case of the rights of citizens? If not, why not? Given that the human rights of migrants are a subset of the rights of all human beings, to answer this question we first need to examine the political implications of universal human rights.

\section{Universality and Political Role of Human Rights}

It is a broadly shared intuition that human rights are the rights of all human beings. While there are disputes over human rights' temporal dimension, the spatial one seems rather uncontroversial - that human beings in all places are entitled to human rights ${ }^{3}$. The universality of human rights is reflected in their current political role in three respects including the scope of institutions, the nature of the political role, and the nature of the justification of human rights. Let me briefly explain.

\section{Universal Scope}

If human rights are the rights of all human beings, then all human beings have human rights against all political institutions. We normally do not think that individuals lose their human rights when they leave the state of their citizenship. ${ }^{4}$ Yet, one may object here that a person surely has a different claim against her own state and other states. In support of this view, one can invoke the famous distinction between perfect and imperfect duties. The argument would be that it is only a claim against one's own state that gives rise to a perfect duty since it is clear that the state of one's citizenship is the duty bearer. When it comes to migrants, however, it is not clear

\footnotetext{
${ }^{3}$ Philosophers disagree whether human rights are timeless, as those grounding human rights in humanity seem to be committed to, or they are synchronically universal, which follows from grounding human rights in contemporary practice. The first view is attributed to the moral conception, while the second is shared by the political conception. Even though I am not concerned with the temporal dimension of human rights here, let me note two difficulties thatrooting human rights in the contemporary practice seems to face. First, it may not support the claim that human rights are synchronically universal for a simple reason that those synchronically existing may not live under the same social conditions. Second, there are good reasons to include human rights entitlements of future people within the scope of universal human rights since future people are significantly affected by the actions of present people. Yet, if social conditions are what matters for human rights entitlements, then future people, meaning those that diachronically exist, have no human rights, even though they are affected by those synchronically existing. This shows how insisting on the present social conditions, rather than actions of those synchronically existing, limits the account of human rights. I am thankful to Bob Goodin for pointing this out.

${ }^{4}$ Depending on circumstances, persons crossing borders may lose their citizenship rights. But even this is restricted since no state is allowed to revoke the citizenship rights of persons that have not previously acquired citizenship of another country. The rationale is that no state can make persons stateless. For details, see "Convention Relating to the Status of Stateless Persons," UNHCR, 1954; United Nations High Commissioner for Refugees, "Convention on the Reduction of Statelessness," UNHCR, 1961.
} 
which states are duty bearers and on what grounds they can hold these duties. Hence, the human rights of migrants do not correlate with perfect duties, and accordingly, are not rights sensu stricto. However, when it comes to the human rights of migrants, what is morally relevant is not the specification of duty bearers, but its specifiability (Griffin 2008, pp. 108-10). For instance, to secure a higher standard of protection for asylum seekers, the European Union has enacted the so-called Dublin Regulation. The Dublin Regulation sets a hierarchy of criteria for identifying the EU member states responsible for the examination of asylum claims in Europe, such as family links or the country of the first entry. ${ }^{5}$ This shows that allocating responsibilities is practical, rather than a normative question. Accordingly, the human rights of migrants are not less important just because they are rights against all political institutions.

\section{Evaluative Role}

The universality of human rights is also reflected in the nature of their political role. Namely, human rights serve as evaluative standards for all political institutions in two senses. First, universal entitlements give us critical leverage to evaluate existing institutions. For instance, human rights records of states include, among the rest, their treatment of migrants. Second, the universality of human rights can also help us search for alternative forms of institutional arrangements that can better protect them.

One might object here that insisting on the evaluative role of human rights is based on understanding these rights as standards rather than claims. The problem with taking human rights as standards is that it decreases their moral weight in the sense that it shifts the focus from human rights violations to human rights unfulfillment (Valentini 2012). However, the objection is grounded in a narrow understanding of human rights' evaluative role for there is no reason to think that emphasizing their evaluative role commits one to take human rights as standards only. Indeed, one can argue that institutions are evaluated precisely based on how much they respect rights as claims.

\section{The Nature of Justification}

\footnotetext{
${ }^{5}$ Regulation (EU) No 604/2013 of the European Parliament and of the Council; "EUR-Lex - 32013R0604 - EN EUR-Lex," 2013.
} 
Finally, the universality of human rights is intrinsically related to the way they are justified, i.e. they are justified by their significance for right holders. This constrains what kind of justification of human rights is appropriate. For instance, the principle of non-refoulement, which is the bedrock principle of international refugee law, holds that state parties cannot send the refugees back to their home state if there is a risk that they will face persecution. The non-refoulement principle is justified by protecting the basic interests of refugees, including their right to life and

protection from torture. ${ }^{6}$ Therefore, it is only if human rights are properly justified that they can play a political role against all political institutions.

In sum, the universality of human rights shapes their political role in a sense that these are rights against all political institutions, they help us evaluate these institutions and they are justified by their importance for right holders. Importantly, these considerations are not theoretical only, but they characterize the contemporary practice, too. These considerations notwithstanding, we could see that the existing practice is also characterized by what I defined as the trade-off problem-that states too easily trade-off the rights of migrants for the rights of their citizens, thus decreasing a normative significance of the former. While the existing legal entitlements may give us some ground to criticize such practice, it is not sufficient since the legal rights of citizens will always prevail. This reveals a fundamental tension between the rights of citizenship on the one hand and universal human rights on the other. Resolving the tension, however, is a too large task to undertake here. What I intend to do instead is to examine which conception of human rights can give migrants' rights more weight. This is important since it will help us conceptualize a political role the human rights of migrants can play against foreign states. To do so, I will go back to the debate between the political and moral conception of human rights.

\section{Human Rights, Legitimacy and Justification}

So far, I have argued that the fact that states too easily trade-off the human rights of migrants for those of their citizens creates a problem for a broadly shared view that human rights are rights of all human beings. Therefore, any conception of human rights as the universal entitlement of all human beings has to be able to constrain such trade-offs, meaning that it has to offer an account

\footnotetext{
6 "UNHCR 1951 Convention and Protocol Relating to the Status of Refugees," art. 33.
} 
of human rights such that it gives more weight to the human rights of migrants. This need not necessarily lead to outweighing rights of citizens but can at least constrain a set of reasons governments can invoke to justify such trade-offs. How much weight the human rights of migrants might have depends on the way we understand these rights. Here I will assess which of the two dominant understandings of human rights - the political conception or the moral one can better address the trade-off problem.

\section{Conceptual Framework}

To examine which conception can better address the trade-off problem, we need to start from the way they understand human rights. This might appear like an impossible task to do since two conceptions of human rights aim for different things. Namely, the political conception mostly attempts to define human rights, while the moral conception is focused on their justification. ${ }^{7}$ More specifically, the political conception defines human rights in relation to the role they play in practice as constituting a set of necessary, though not sufficient standards that states should comply with. On the other hand, the moral conception focuses on justifying human rights on practice-independent grounds. While the two approaches might appear impossible to compare, we should bear in mind that even though separate, the role of human rights and their justification are interdependent notions. For, human rights cannot play a role against political institutions unless they are properly justified. Also, the features of their political role affect the way we want to justify them. An important part of philosophizing about human rights is to get the relation between the role of human rights and their justification right.

To make a comparison between the political and the moral conception possible, I will use a modified version of Williams's distinction between "internal" and "external" reasons (Williams 1982). I shall not attempt any discussion of the distinction as such but will take it at its face value as a useful conceptual tool. The difference between internal and external reasons may be stated as follows.

Internal reason: A has a reason to $\Phi$. The proposition is true if and only if A has an aim that will be served by his $\Phi$-ing.

\footnotetext{
${ }^{7}$ I am thankful to Laura Valentini for helping me clarify this.
} 
External reason: There is a reason for A to $\Phi$. The truth of the proposition is not relative to the agent's subjective motivational set. ${ }^{8}$

I depart from Williams's distinction in two respects. First, I use external reasons in a form of "ought," while Williams does not discuss the external reasons in relation to morality. Second, I modify the distinction by introducing two versions of internal reasons. I will call these "actual" and "deliberated" internal reasons. I introduce this modification in order to more accurately capture the political conception's understanding of human rights. Here is the modified version of distinction:

Actual internal reason: A has an actual reason to $\Phi$.

Deliberated internal reason: A would have a reason to $\Phi$ if he had deliberated from his subjective motivational set.

Therefore, while both forms of internal reasons rely on the existence of the subjective motivational set of the agent to $\Phi$, the difference is that in the first case it is the actual reason for A to $\Phi$, whereas in the second a reason to $\Phi$ would come as a result of internal deliberation.

One can argue that the moral conception takes human rights as the external reasons, i.e. reasons whose validity is independent of a subjective motivational set of agents. On the other hand, the political conception seems to be closer to defining human rights as the deliberated internal reasons, i.e. reasons that agents would endorse had they deliberated from their subjective motivational sets. Defining the political conception this way seems to successfully capture its central components: definitional one (role human rights play in practice) as well as normative one (grounding human rights in interests). In the next two sections, I will assess which kind of reasons can yield an account of human rights able to avoid the trade-off problem.

One may object that the political conception appeals to the actual internal reasons since it insists that the justification of certain claims depends on their coherence with the practice. This would mean that the political conception mirrors what is known as a sociological approach to legitimacy which draws on the Weberian tradition of insisting on the importance of the perceptions a society's members share about their states. In this sense, we count as legitimate

\footnotetext{
${ }^{8}$ My specification departs from Williams's idea of external reasons since for him the validity of the proposition stating reasons for action is conditional upon the existence of agent's subjective motivational set. The proposition "There is a reason for A to $\Phi "$ cannot be true unless there is the subjective motivation for agent A to deliberate from. However, if deliberation is conducted on the basis of subjective motivation, following Williams, then this is not an external reason anymore. It follows that propositions stating external reasons are necessarily false. Since I am using external reasons in the form of "ought," I do not consider its validity conditional upon the existence of a subjective motivational set.
} 
those states that are actually accepted by their members. The sociological approach, however, does not seem to be able to assess the legitimacy from a moral point of view since the normative relevance of existing beliefs can easily be contested. For, members can be simply mistaken by way of indoctrination or a simple error in judgment (Simmons 1999). If the political conception indeed mirrors the sociological approach, then the same objections apply to it, too. Yet, the political conception does not seem to be conventionalist to that extent. For instance, Beitz argues that the political conception is different from "agreement" accounts of human rights in that the latter derives justification of human rights from an intercultural agreement, while the political conception grounds human rights in interests that are "sufficiently generic that it would be reasonable to expect anyone to recognize their importance" (Beitz 2009, pp. 136-37). I take it that insisting on the reasonable expectation of acceptability shows that the political conception proponents would endorse a version of the deliberated internal reasons to explain human rights.

\section{a) The Political Conception}

The political conception defines human rights as a sui generis normative practice meaning that they represent a set of norms for a class of agents and that it is broadly believed that these norms should be complied with. Human rights are the normative practice in the sense that we have to have reasons to endorse them as a practice. The method of interpreting the practice aims to provide a non-parochial normative foundation of human rights. More precisely, defining the nature of human rights by interpreting the practice aims to separate the question of the nature of human rights from its content and scope. While the content of human rights may remain a point of dispute, a reference to the role human rights play in the practice, on this view, shows in an uncontroversial way what human rights are. Thus, human rights are rights individuals have primarily against their own states (Beitz 2009, pp. 105-08). Besides playing a role as the legitimating condition of states, human rights may also give pro tanto reasons for the interference by external agents in the case of noncompliance by a state (Rawls 1999; Raz 2007; Beitz 2009).

If human rights are to legitimate states then they have to be justified by reasons acceptable to states. As we can see, insisting on the role of human rights as their defining feature allows global pluralism to constrain the justification of human rights. However, the political 
conception surely does not want to leave human rights entirely dependent upon the acceptance by all states. Instead, it implies that there is a form of mutual constraint between the idea of human rights and states' acceptance which I have tried to capture by introducing the concept of "deliberated internal reasons". As a small reminder, the deliberated internal reasons are the reasons that the agent would come up with by deliberating from her actual beliefs and motivations. The reliance on the deliberated internal reasons supposes to yield an account of human rights consistent with different justifications. As one of its proponents argue, human rights are a public reason formulated autonomously from any tradition that can reasonably be expected to be shared by adherents of conflicting traditions (Cohen 2006). ${ }^{9}$ What can human rights so defined say about the trade-off problem? By defining human rights as a necessary condition of a state's legitimacy, it might seem that it can easily include the human rights of migrants as one of these conditions and by doing so, give us a much-needed critical tool to address the trade-off problem. Yet, I do not think this is the case. In the next section, I give reasons to support this skepticism.

\section{Human Rights as Deliberated Internal Reasons}

As argued earlier, the trade-off problem illustrates the way states often trade-off the human rights of migrants for those of their citizens. Yet, if we indeed think that human rights are the rights of all human beings, we need to formulate an account of human rights such that makes them copossible with the rights of citizens. Here I will offer several reasons for why human rights defined as the deliberated internal reasons cannot achieve this.

First, the political conception grounds human rights in universal interests. For example, Beitz holds that human rights protect urgent individual interests against standard threats, most of which are threats by their own governments (Beitz 2009, p. 207). The appeal to universal interests can count as an adequate justification of human rights since it focuses on the significance of rights for right holders. However, there are difficulties in grounding human rights

\footnotetext{
${ }^{9}$ Recently, it has been argued that the justification of human rights should rely on the principle of inclusion of all, rather than on the idea of "autonomous" formulation of human rights as a public reason since the principle of inclusion legitimizes many forms of existing societies. For this argument see Peter, "The Human Right to Political Participation"; Restated in Fabienne Peter, "A Human Right to Democracy?," in Philosophical Foundations of Human Rights, 2015, 481-90.
} 
solely in interests, no matter how universal they may be. Namely, interests often go beyond rights, for persons can have interests in things that they have no right to. I can have an interest in person X, but it hardly follows that I have a right to his love. Rights also go beyond interests in the sense that persons have rights to things they may have no interest for, such as a right to assemble (O’Neill 2015, p. 72). Furthermore, grounding human rights solely in interests might allow the sacrifice of interests of individuals for the sake of maximizing interests across persons (Tasioulas 2015). Therefore, it is not clear how grounding human rights solely in interests would make the human rights of migrants and those of citizens co-possible and accordingly, resolve the trade-off problem.

Second, defining human rights as the deliberated internal reasons, in order to be successful, has to carefully balance between the requirement of relying on the subjective motivational set and the requirement of yielding public justification of human rights. The account of the deliberated internal reasons will be coherent only if it achieves internalization, i.e. acceptability and still remains public. In this respect, the political conception faces a twofold difficulty. First, it might run into an internal incoherence. Imagine that a government of country $\mathrm{X}$, characterized as an illiberal but legitimate country, treats immigrants differently in respect of civil rights, e.g. imprison them without a trial. ${ }^{10}$ It is not clear what the political conception's proponents would say. On the one hand, since the political conception considers inegalitarian societies legitimate, it may seem that it would not condemn the discriminatory treatment of immigrants. On the other hand, such treatment significantly endangers the interests of immigrants, so on this ground, the political conception may condemn the discriminatory treatment. But the conception cannot yield the account of human rights that would both condemn and not condemn instances of human rights violations. Second, insisting on the acceptability of human rights implies an individual dependence on a particular society. For instance, human rights are defined as the norm of membership in society (Cohen 2006, p. 136). It has already been objected that insisting that human rights are rights against states entails that without the states there would be no rights thus making us "hostage to historical fortune" (Barry and Southwood 2011, p. 378). Also, the view is the status quo biased for it ties human rights to the evaluation of states only (Valentini 2012). The problem generated by such a state-centered view

\footnotetext{
${ }^{10}$ The political conception is based on the understanding that equal possession of rights is a matter of justice, rather than legitimacy. Consequently, legitimate regimes need not be egalitarian. Rawls, The Law of Peoples. p. 69
} 
is not only the difficulty of its application to other forms of political institutions but also its application to relations between states and all right holders. By connecting human rights to membership, the political conception implies that justification of human rights is owed to members only. However, as I argued earlier, if the coercive impact of states' institutions is what is to be justified, then the justification of such an impact is also owed to those attempting to enter (Abizadeh 2008).

I said earlier that philosophizing about human rights requires getting the relation between their role and their justification right. It seems that the political conception gets it in the wrong direction. By defining human rights in relation to the role they play in practice, it allows to value pluralism to have excessive influence over the justification of human rights. The suggestion seems to be that given the value pluralism, human rights have to be acceptable to different states. It follows that persons can claim only those rights that are so acceptable to states. Insisting on acceptability, no matter how hypothetical it can be, seems to misunderstand the point of human rights. To justify human rights is to explain why they are claimable against states, and they cannot be claimable because they are acceptable to states. This shows not only that the insistence on pluralism is thinning justification of human rights as O’Neill has recently argued (O'Neill 2016) but also that insisting on it makes it inadequate to explain a critical role human rights play in the practice. By implication, the trade-off between the human rights of migrants and those of citizens, in this view, would not appear a problem at all, for the rights of citizens can always prevail. But, if stepping aside the human rights of migrants does not appear as a reason to criticize states, then indeed it is not clear in what sense migrants have human rights at all. In sum, it seems that human rights defined as the deliberated internal reasons cannot explain in what sense the human rights of migrants are claimable against foreign states. I turn to the moral conception now.

\section{b) The Moral Conception}

Given that proponents of the moral conception have not directly engaged with the task of conceptualizing the political role of human rights, I take on that task here. I will offer an account that aims to address the long-standing objection that the moral conception cannot account for the political role human rights play against states since it grounds human rights in moral rights. For, 
if a violation of personhood is what matters, then all those violating it, either individuals or institutions, are considered violators in the same sense (Beitz 2009; Barry and Southwood 2011; Valentini2012). It follows that the moral conception cannot capture what is distinctive about the state's violation of human rights, and consequently, is incapable of criticizing existing human rights practices ( $\operatorname{Raz} 2007)$. I address the objection in two steps. First, I will explain how justifying human rights on the grounds of common humanity can help us solve the trade-off problem, and second, I will show how the moral conception can account for political nature of human rights.

\section{Human Rights as External Reasons}

I already suggested that the moral conception can justify human rights as the external reasons and it is a high time to explain what I mean by this. The moral conception's main claim is that human rights are moral entitlements that human beings have by virtue of common humanity. I consider the appeal to a common humanity an external reason since it is defined independently from the practice. The appeal to common humanity is objected on the grounds that we actually cannot define common humanity, and consequently, it is not clear why people are equally entitled to human rights (Buchanan 2010). It is presumed that we cannot move on to discuss the latter until we find a satisfactory answer to the former. Call this the Skeptic View. Let me take a closer look at the Skeptic view.

Here I introduce a distinction between equality in grounding human rights and equality in entitlement to human rights.

Equality in grounding human rights: all human beings are entitled to human rights by virtue of equal possession of property $\mathrm{X}$.

Equal entitlement to human rights: all human beings are equally entitled to human rights.

The Skeptic View holds that there is a conditional relation between the two propositions. If human beings equally possess property $\mathrm{X}$, they are equally entitled to human rights. So far, so good. The problem comes with the next argumentative step which holds that there are no properties equally possessed by all human beings, and consequently, there can be no equal entitlement to human rights. In some views, empirical properties vary in degrees across persons and so call for establishing a threshold of properties in order to recognize the status of morally 
equal. Yet, the conditions of severally mentally disabled humans and highly cognitive nonhuman animals make the nonarbitrary establishing a threshold for recognizing equal moral status impossible. Consequently, we cannot establish moral equality of human beings either (Arneson 1999).

This claim, however, is troublesome since it is only if we knew for sure that there is absolutely no feature common to all human beings in such a way, that we could infer that equality in grounding human rights fails. But we still have no reason to believe that it is more likely that there is no such property equally shared across humanity. Following the principle of insufficient reason (Sinn1980), in a case there is no reason to believe that it is more likely that there is no property that is equally shared across humanity rather than that there is, we should assume that both outcomes are equally probable. ${ }^{11}$ Therefore, the epistemic limits we face in establishing what property is equally shared across humanity give us a reason to presume that there is an equal chance of both positive and negative outcomes. If both outcomes are equally probable, we should presume equal possession of properties across humanity given what is at stake, i.e. establishing the fundamental moral status of all human beings. It follows that whatever we think the grounds of human rights are, human beings are equally entitled to human rights.

Note that there are also normative reasons for avoiding any argumentative conundrum concerning the grounds of moral equality. For instance, one could say that respect for the dignity of human beings does not permit any consideration of their scalar properties (Carter 2011). Or, one could argue that attributing equal moral worth to everyone does not imply ascribing any properties, but rather amounts to expressing an attitude of respect toward the humanity in each person (Feinberg 1973, pp. 84-85). Thus, the attitude of equal respect has independent value and is not grounded in anything more ultimate.

The proposition that all human beings are equally morally entitled to human rights has twofold implications for the political role human rights play. First, all human beings are entitled to human rights against all agents, including all political institutions. Second, common humanity not only gives all human beings claims against all agents, but it also generates a reason for it. It is precisely because human rights are universal in virtue of common humanity that all human beings have rights against all agents, including political institutions.

\footnotetext{
${ }^{11}$ I thank Bob Goodin for drawing my attention to the principle.
} 
What does this tell us about the trade-off between the human rights of migrants and those of citizens? I will leave specific implications for the last section. As a general point, grounding human rights in common humanity gives more weight to the claims of migrants. To be sure, basic moral equality does not entail any kind of more robust equal status for this necessitates a further argument. What is important is that grounding human rights in the common humanity would count as an exclusionary reason against some considerations, such as maximizing interests of citizens. If all human beings have the status of morally equal, then the interests of everyone count equally. It follows that no person's human rights can be traded off by appeal to aggregated interests of others (Tasioulas2015). However, it remains to be seen if and if so, how the moral conception, at least the version I am defending here, can account for the political role of human rights.

\section{The Political Role of Human Rights}

The moral conception is often characterized as being incapable of criticizing the human rights practice since it allegedly cannot account for political role human rights play against institutions. For the ease of exposition, I will break the objection into two claims. First, the objection states that the moral conception, by considering human rights moral rights, cannot account for their claimability. Second, it also cannot address the role human rights play against institutions. In response, I make two related claims. First, I argue that moral rights are consistent with understanding human rights as claim rights. Second, I also argue that even though claims against everyone, moral rights are still important as claims against institutions.

\section{i. Claim rights}

Human rights are mostly defined as individual claims that political institutions have a duty to fulfil (Barry and Southwood 2011). Following Hohfeld's famous taxonomy, claim rights are rights in the strictest sense since they correlate with the duties of others (Hohfeld 1913). When duty bearers reject claims, they effectively violate human rights. By defining human rights as pre-institutional, so the objection goes, the moral conception cannot account for human rights as 
claim rights. The reason for this is that moral rights are rights against all other individuals, and as such are not claim rights proper (Valentini 2012).

However, taking human rights as moral rights gives rise to their claimability at least in two ways. First, the entailment of duty cannot explain the moral significance of having a human right (Thomson 1990, p. 59). Instead, it is the features of human beings, such as individual interests, that are the sources of claims. That said, the reliance on interests does not suffice; instead, it is the moral equality of human beings that gives normative significance to their universal interests. In other words, it is because of the equal moral status of everyone that universal interests can ground human rights and so impose duties on others (Tasioulas 2015). Furthermore, moral rights can be described as abstract "cluster" rights and as such morally significant in at least two respects. First, abstract rights give rise to specific rights in specific institutional settings. In other words, it is institutions that specify the content of rights as well as of correlated duties (Gilabert 2011). Another important implication of connecting human rights to abstract moral rights and personhood is that it can explain in what sense human rights are inalienable, and accordingly, can protect from the government's actions. The inalienable character of rights prevents governments from causing the alterations in the rights without authorization by those affected (Thomson 1990, pp. 280-86).

\section{ii. Rights against institutions}

Human rights are defined as rights individuals have against institutions due to crucial role institutions play in relation to human rights. Namely, institutions are capable both of significantly violating human rights as well as of promoting them. Specifying human rights as a subset of moral rights, it is said, cannot account for this, since moral rights are pre-institutional. This objection involves two related claims: first, human rights as moral rights can exist without institutions. Second, human rights as moral rights are rights individuals have against one another, which cannot account for the distinctiveness of the institutional human rights violations.

The objection that human rights cannot be moral rights since the former cannot exist without institutions, while the latter can, targets Lockean accounts of natural rights. Yet, one may take a Kantian view and argue that human rights may be characterized as pre-institutional individual entitlements the guaranteeing of which requires establishing political institutions 
(Valentini 2012). Thus, the relation between human rights and political institutions is more abstract in the sense that the fulfillment of human rights requires political institutions as duty bearers. The claim that individuals have pre-institutional entitlements can also explain entitlements against existing institutions. For instance, there may be a moral right to free speech, but it is only after institutions are in place that we get a more specific right such as the right to free press or free access to information. Therefore, moral rights not only need to be specified by institutions but also give individuals entitlements against institutions once they are in place.

In this section, I argued that grounding human rights in moral rights has important implications for their political role. Namely, the moral nature of rights can explain two defining features of human rights - their claimability as well as their inalienability. In addition, I have followed a Kantian understanding that moral rights not only require an institutional specification but can also explain rights against institutions once institutions are in place. Based on this, it seems that the moral conception can offer a coherent account of the political role that human rights play against all institutions. I turn now to derive more concrete implications for the relationship between migrants and states.

\section{Going Back to Migrants}

Thinking about human rights as moral rights can help us explain claims of migrants against foreign states in two ways - by showing how violation of their rights by their own states gives rise to claims against foreign states, but also how migrants have claims against foreign states independent from the way they are treated by their own states. First, it can be argued that a violation of A's right by $\mathrm{X}$ entitles him to a claim against Y. For instance, individuals that fall victims of a crime, have a claim against the police. Analogously, persons whose rights are violated by their states have claims against other states, similar to those asylum seekers have. A right does not cease to be a right if it is violated by a primary duty bearer. In addition to claims generated by violations of human rights, human rights also entail different claims against different duty bearers. I may have a claim against state B even if my state A has not violated my rights. To illustrate the point, let me use an analogy. A child has a claim against its parents to a certain kind of treatment. The child's special relationship with its parents generates special rights for it. Now, imagine the child visiting its parents' friends. The child, even though having its 
parents as the primary duty bearers, still has a claim against its hosts to a certain treatment. Yet, it is entitled to this specific treatment, not because of special rights it has against its parents, but because of its status as a human being, or more precisely - a child. Analogously, I have claims against the state B irrespective of claims I may have against the state A if I happen to be affected by, or for the purpose of the present discussion, have arrived at the borders of the state B. In sum, while violation of human rights by their own states is sufficient to give rise to claims against foreign states, it is not necessary since migrants have claims against foreign states irrespective of the way they are treated by their own states. I deliberately use the vague phrase "a certain kind of treatment" for it is difficult to exactly specify what that treatment in all cases entails.

Second, grounding human rights in common humanity gives each migrant a claim against states on an individual basis in the sense that they are entitled to a dignified treatment as individuals. Insisting on the equal moral status of all human beings which entails equal significance of interests of each and every one of them implies that states cannot justify the trade-off between the human rights of migrants and those of citizens by appealing to the maximization of interests of the latter. To be sure, this does not entail that governments cannot put more weight on the interests of their citizens, but doing so has to be justified on grounds other than the maximization of their interests, which in turn makes such trade-off more difficult to justify.

Third, insisting on the equal importance of interests requires an individualistic approach in the sense that foreign governments are to assess individual applications to entry on an individual case-by-case basis by taking into account particular circumstances of migrants. This can have important implications for existing policies. For instance, the burden-sharing policy currently employed to deal with the refugee crisis, where states unilaterally accept to take in a certain number of refugees, has to be constrained by individual assessments. This means that it is not only numbers that count when deciding whom to take in, but also particular circumstances of each and every applicant, such as her family ties.

Fourth, moral rights as a normative idea give us a useful tool not only to criticize the practice but also to question the limits of the existing legal entitlements. Namely, if we accept that human rights are moral rights, then we have a sufficiently firm ground to question justifiability of existing legal rights. For instance, we can question the present distinction between refugees and the so-called economic migrants and argue that the category of refugees 
should also be extended to all those fleeing from poverty and natural disasters. As I mentioned earlier, violation of human rights by one's state is not necessary to give rise to her claims against foreign states.

Finally, acknowledging that the human rights of migrants indeed play a role against foreign states enriches the set of evaluative criteria we currently possess for political institutions. Thus, apart from being a condition of the legitimacy of states in relation to their citizens, one can argue that the treatment of migrants should be a part of assessing the state's legitimacy as well. This would give us a valuable critical tool to assess practices of all states, no matter how democratic they might be.

\section{Conclusion}

In this chapter, I tried to articulate possible political implications of universal human rights by focusing on the relationship between migrants and states. I argued that the fact that states too easily trade-off the human rights of migrants for those of their citizens creates a problem for a broadly shared view that human rights are rights of all human beings. Therefore, any conception of human rights as universal entitlements has to be able to constrain such trade-offs, meaning that it has to offer an account of human rights such that it allows the co-possibility of the human rights of migrants and those of citizens.

I examined which of the two dominant conceptions of human rights -the political and the moral one - can offer a better account of such co-possibility. In this respect, I made two claims. First, I argued that the political conception, by defining human rights in relation to the role they play, yields an account of human rights as the deliberated internal reasons, which does not seem to give proper weight to the human rights of migrants, and consequently, cannot solve the tradeoff problem. Second, I have also argued that the moral conception, by grounding human rights in the common humanity, can secure more weight for the human rights of migrants and accordingly, rule out the maximization of interests of citizens as the justification for the tradeoff.

Since the trade-off problem ultimately concerns the justification of human rights, I have conducted the discussion at a very abstract level, leaving aside numerous intricate details concerning the relationship between states and migrants. My aim has not been to offer a full account of such relations, but only to explain their nature. Therefore, I have only scratched a 
surface and more work needs to be done to fully explicate the political implications of human rights taken as moral rights. Such a project is worth pursuing, for it can help us remove the obstacles to the fulfillment of human rights that the present state system creates.

\section{Bibliography}

Abizadeh, A. (2008) "Democratic Theory and Border Coercion No Right to Unilaterally Control Your Own Borders," Political Theory vol. 36 no. 1, pp. 37-65.

Arneson, R. J. (1999) “What, If Anything, Renders All Humans Morally Equal?," in Jamieson Dale (ed.), Singer and His Critics, Oxford: Wiley-Blackwell, pp. 103-28.

Barry, C. and Southwood, N. (2011) "What Is Special About Human Rights?," Ethics and International Affairs, vol. 25 no. 3, pp. 369-83.

Beitz, C. R. (2001) "Human Rights as a Common Concern," American Political Science Review, vol. 2, pp. 269-82.

(2009) The Idea of Human Rights. Oxford: Oxford University Press.

Buchanan, A. (2010) "The Egalitarianism of Human Rights," Ethics, vol. 120 no. 4,pp. 679-710.

Carter, I. (2011) "Respect and the Basis of Equality," Ethics, vol. 121 no. 3, pp. 538-71.

Cohen, J. (2006) "Is There a Human Right to Democracy?," in Sypnowich, C. (ed.),The Egalitarian Conscience: Essays in Honour of G. A. Cohen, New York: Oxford University Press, pp. 226-46.

"EUR-Lex - 32013R0604 - EN - EUR-Lex,", Regulation No 604/2013 of the European Parliament and the Council, available at http://eur-lex.europa.eu/legalcontent/en/ALL/?uri=celex\%3A32013R0604

Feinberg, J. (1973) "Human Rights," in Social Philosophy. Prentice Hall, New Jersey, pp. 84-88. Gilabert, P. (2011) "Humanist and Political Perspectives on Human Rights," Political Theory, vol. 39 no. 4, pp. 439-67.

Goodin, R. E. (2007) "Enfranchising All Affected Interests, and Its Alternatives, "Philosophy and Public Affairs, vol. 35 no. 1, pp. 40-68.

Griffin, J. (2008) On Human Rights, Oxford; New York: Oxford University Press.

Hohfeld, Wesley N. (1913) 'Some Fundamental Legal Conceptions as Applied in Judicial Reasoning', The Yale Law Journal, vol. 23 no. 1, pp. 16-59. 
"International Convention on the Protection of the Rights of All Migrant Workers and Members of Their Families," 1990. General Assembly resolution 45/158 of18 December 1990, available at www.ohchr.org/EN/ProfessionalInterest/Pages/CMW.aspx

Miklosi, Z. (2012) "Against the Principle of All Affected Interests," Social Theory and Practice, vol. 38 no. 3, pp. 483-503.

O'Neill, O. (2016) "Pluralism, Positivism and the Justification of Human Rights," in Justice Across Boundaries, Cambridge: Cambridge University Press, pp. 120-34.

(2015) "Response to John Tasioulas," in Cruft, Liao and Renzo (eds.), Philosophical Foundations of Human Rights, Oxford: Oxford University Press, pp. 71-78.

Peter, F. (2015) “A Human Right to Democracy?," in Cruft, Liao and Renzo (eds.),Philosophical Foundations of Human Rights, Oxford: Oxford University Press, pp. 481-90.

(2013) "The Human Right to Political Participation," Journal of Ethics \& Social Philosophy, vol. 7 no. 2, pp. 1-16.

Rawls, J. (1999) The Law of Peoples: With, The Idea of Public Reason Revisited, Cambridge, Mass: Harvard University Press.

Raz, J. (2007) "Human Rights without Foundations," Oxford Legal Studies Research Paper, vol. 14.

"Convention on the Reduction of Statelessness." UNHCR, 1961.

"Convention Relating to the Status of Stateless Persons." UNHCR, 2016.

Simmons, A. J. (2000) Justification and Legitimacy: Essays on Rights and Obligations, Cambridge, UK; New York, NY, USA: Cambridge University Press.

(1999) “Justification and Legitimacy,” Ethics, vol. 109 no. 4, pp. 739-71.

Sinn, H. W. (1980) "A Rehabilitation of the Principle of Insufficient Reason", The Quarterly Journal of Economics, vol. 94 no. 3, pp. 493-506.

Tasioulas, J. (2015) "On the Foundations of Human Rights," in Cruft, Liao and Renzo (eds.), Philosophical Foundations of Human Rights, Oxford: Oxford University Press, pp. 45-70.

Thomson, J. J. (1990) The Realm of Rights, Cambridge, Mass: Harvard University Press.

"UN International Migration Report 2015: Highlights", United Nations, Department of Economic and Social Affairs, ST/EAS/ESR.A/375, available at www.un.org/en/development/desa/population/migration/publications/migrationreport/docs/Migra tionReport2015_Highlights.pdf 
"Convention and Protocol Relating to the Status of Refugees." UNHCR, 1951

Valentini, L. (2012) “Human Rights, Freedom, and Political Authority,” Political Theory, vol. 40 no. 5, pp. 573-601.

(2012a) "In What Sense Are Human Rights Political? A Preliminary Exploration,"

Political Studies, vol. 60 no. 1, pp. 180-94.

Williams, B. (1982) Moral Luck, Cambridge: Cambridge University Press. 